DE DE GRUYTER OPEN
Research Article

(C) 2017 Friday Ademola Ajagbe and Joshua Olusegun Ajetomobi. This is an open access article licensed under the Creative Commons Attribution-NonCommercial-NoDerivs License (http://creativecommons.org/licenses/by-nc-nd/3.0/).

\title{
Impact of Investment Climate on Total Factor Productivity of Manufacturing Industries in Nigeria
}

\author{
Friday Ademola Ajagbe \\ Lecturer, Federal University of Agriculture, \\ Abeokuta, Nigeria \\ Joshua Olusegun Ajetomobi \\ Professor of Production Economics, \\ Ladoke Akintola University of Technology, \\ Ogbomoso Nigeria
}

Doi: $10.1515 / m j s s-2017-0015$

\begin{abstract}
This study examines the influence of investment climate on productivity of manufacturing industries in Nigeria. The study is conducted in two phases: in the first phase, an econometric production function for Nigerian manufacturing industries is estimated to produce a measure of TFP for each firm; in the second stage, variation in the TFP is statistically related to indicators of the investment climate as well as firm characteristics. The analyses use 2009 World Bank Enterprise survey data on Nigeria. The results show systematic variations in the investment climate indicators, across various industries in Nigeria. The following indicators of poor investment climate: power outage, unofficial payment, loss in transit due to breakage or spoilage and tax burdens, have significant negative effects on TFP of manufacturing industries in Nigeria. Increasing power outage by one hour per month could reduce TFP by $0.06 \%$, while a $1 \%$ rise in unofficial payment could lead to about $1.8 \%$ decline in TFP. Investment climate indicators, such as, management time in dealing with regulations and percentage of firms owned by private domestic individuals, companies and organizations have positive effects on TFP of manufacturing industries.
\end{abstract}

Keywords: Investment Climate, Total Factor Productivity, Nigeria

\section{Introduction}

In Nigeria, evidence of lower productivity relative to other developing nations is well documented by Larossi and Clarke (2011). They discovered that Firms in Kenya were about 40 percent more efficient than firms in Nigeria, firms in Russia were almost twice as productive, and firms in South Africa almost four times as productive. In various developing countries, such differences have been attributed to two main factors, first, the internal factors such as technology, capital, labour, and marketing strategies. The second factor involves investment climate such as government policy and environment in which the industries operate. Up till now, very few studies have tried to find an explanation of the poor performance of manufacturing firms in Nigeria. Two major research which employed firm level data to explore performance of Nigerian manufacturing industries were Seliola and Seker (2011) and Larrossi and Clarke (2011). The former classified Nigeria among nations with low average TFP in food, garment and chemical industries while the latter merely described the extent of investment climate problems in Nigerian cities. Other studies (Chete and Adenikinju, 2002 
and Ajetomobi 2011) employed time series data. Chete and Adenikinju 2002 investigated the roles of trade policies in fostering productivity growth in Nigerian manufacturing sector between 1962 and 1985. They found positive correlation between trade liberalization and productivity growth. Ajetomobi (2011) included Nigeria in his study of the total factor productivity of selected agricultural commodities in ECOWAS. The study showed a better productivity for the nation's agriculture than when it was included in the estimates of the productivity of agriculture in Africa. Generally speaking, specific work on firm level performance of manufacturing firms is scanty in developing nations. The closest so far have been Veeramani and Goldar (2004) on India, Escribano and Guasch (2005) on Guatemala, Hondura and Nicaragua as well as Dollar et.al., (2005) and Bastor (2004). A major reason for this has been lack of reliable and adequate firm level data.

Against the above background and given availability of World Bank Enterprise data on Nigeria, which cover about 26 cities and 15 manufacturing industries, the research questions of interest in this study are: (i) what are the productivity levels of manufacturing industries in Nigeria and (ii) what is the influence of investment climates on the TFP of manufacturing industries in Nigeria? Hence the following are the research objectives; to

i. Estimate the total factor productivity across manufacturing industries in Nigeria

ii. Analyze the effects of investment climate on the total factor productivity of manufacturing industries in Nigeria

In view of the above stated specific objectives, the following hypotheses were tested. There is no difference among the TFP of manufacturing industries in Nigeria. There is no relationship between total factor productivity and investment climate of manufacturing industries in Nigeria.

\section{Literature Review}

\subsection{Measurement of Productivity}

The two major rationales for choice of productivity measurement methods are (i) the purpose of productivity measurement and, in many instances, (ii) the availability of data. Table 1 enumerates the main productivity measures. The partial measures in columns 2 and 3 were restricted to labour and capital productivity, these are the most frequently used partial factor productivity measures. The total factor productivity too is either in the form of capital-labour TFP, based on a value-added concept of output, or in the form of capital-labour-energy-materials TFP (KLEMS), based on a concept of gross output. Among those measures, value-added based labour productivity is the single most frequently computed productivity statistic, followed by capital-labour TFP (Mayer and Ottaviano, 2007).

Table 1: Overview of Main Firm-level Productivity Measures

\begin{tabular}{|l|l|l|l|l|}
\hline \multirow{2}{*}{ Types of output } & \multicolumn{4}{|l|}{ Types of input measures } \\
\cline { 2 - 5 } & Labour & Capital & Capital-labour & $\begin{array}{l}\text { Capital Labour and } \\
\text { intermediate inputs }\end{array}$ \\
\hline Gross output & Labour productivity & Capital productivity & Capital labour TFP & KLEMS TFP \\
\hline Value added & Labour productivity & Capital productivity & Capital labour TFP & - \\
\hline & \multicolumn{2}{|l|}{ Partial Factor Productivity } & Total Factor Productivity \\
\hline
\end{tabular}

In literature, the estimation of TFP has been done using either parametric or non-parametric approach (Solow 1957, Hall 1990, Foster, Haltiwanger and Krizan 1998, Batelsman and Doms 2000, Hulten 2001, Diewert and Nakamura 2002, Jorgenson 2003, Jorgenson, Gollop and Fraumeni 1987, Olley and Pakes 1996 Barro and Sala-i-Martin 2004 and Syverson 2011). In this study, the parametric approach is adopted. The estimation of Total Factor Productivity (TFP) using the parametric approach often involves formulation of various hypotheses regarding the technology of production. The most common ones are the Cobb Douglas and the Translogarithmic production functions. Although both present good mathematical properties, the elasticities of the production to the inputs are easy to read and to interpret with the Cobb Douglass technology. Against the 
background information we estimate a Cobb-Douglas model expressed as follows:

$Y_{i t}=A_{i t} K_{i t} L_{i t} M_{i t}$

In logarithmic form, $\ln \left(Y_{i t}\right)=\ln \left(A_{i t}\right)+\beta_{k} \ln \left(K_{i t}\right)+\beta_{l} \ln \left(L_{i t}\right)+\beta_{m} \ln \left(M_{i t}\right)+\varepsilon_{i t}$

Where $\mathrm{Y}$ is gross output, $\mathrm{K}$ is capital input, $\mathrm{L}$ is labor input, $\mathrm{M}$ is material input, $\varepsilon$ is an unobserved productivity shock, and $i$ index industries. The study assumes that all firms are price takers and wages diverge across various industries. Hence, number of employees is used to define labour variable instead of value units. The natural logarithm of the TFP index is estimated as the residual term in the econometric production function. It is important to bear in mind that the TFP analysis in this study is based on cross-sectional data at the firm level collected in one year or over a relatively short interval. Hence it is assumed that all firms have access to the same level of technology. Thus variations in TFP should be attributed principally to variations in efficiency rather than variations in technology.

In order to control for quality of the firms' management, the year of schooling (educ) of the firms' manager is included in the model. Hence model 2 is expressed as

$$
\ln \left(Y_{i}\right)=\ln \left(A_{i}\right)+\beta_{k} \ln \left(K_{i}\right)+\beta_{l} \ln \left(L_{i}\right)+\beta_{m} \ln \left(M_{i}\right)+\beta_{e} \ln \left(E D U C_{i}\right)+\varepsilon_{i}
$$

Equation 2 and 3 can be estimated using the Ordinary Least Square (OLS) method assuming a consistent exogeneity of inputs and the error term. If all the relevant characteristics of individual firms are controlled for, there should be no relevant unobserved characteristics.

As a form of robustness check, industry dummies are included in the model. The model becomes

$$
\begin{aligned}
& \ln \left(Y_{i}\right)=\ln \left(A_{i}\right)+\beta_{k} \ln \left(K_{i}\right)+\beta_{l} \ln \left(L_{i}\right)+\beta_{m} \ln \left(M_{i}\right)+\text { industry }_{i}+\varepsilon_{i} \\
& \ln \left(Y_{i}\right)=\ln \left(A_{i}\right)+\beta_{k} \ln \left(K_{i}\right)+\beta_{l} \ln \left(L_{i}\right)+\beta_{m} \ln \left(M_{i}\right)+\beta_{e} \ln \left(\text { EDUC }_{i}\right)+\text { industry }_{i}+\varepsilon_{i}
\end{aligned}
$$

Industry in the equations stands for industry dummies. In addition to capturing productivity differences across various industries, industry dummies will control for other unobservable traits such as industrial disputes, trade distortions, and influence of industry-specific policies. The validity of the assumption of common technology is tested by allowing the regression coefficients to vary by industry. The equations are as follows:

$$
\begin{aligned}
& \ln \left(Y_{i}\right)=\ln \left(A_{i}\right)+\beta_{k} \ln \left(K_{i}\right)+\beta_{l} \ln \left(L_{i}\right)+\beta_{m} \ln \left(M_{i}\right)+\beta_{i} \text { industry }{ }_{i} \ln \left(L_{i}\right)+\beta_{j} \text { industry }_{i}{ }^{*} \ln \left(K_{i}\right)+\varepsilon_{i} \\
& \ln \left(Y_{i}\right)=\ln \left(A_{i}\right)+\beta_{k} \ln \left(K_{i}\right)+\beta_{l} \ln \left(L_{i}\right)+\beta_{m} \ln \left(M_{i}\right)+\beta_{e} \ln \left(\text { EDUC }_{i}\right)+\beta_{i} \text { industry } \\
& *
\end{aligned}
$$

\subsection{Investment Climate and Total Factor productivity}

Several methods have been developed to explain relationship between IC and firm-level productivity. These include: OLS, Solow growth model, fixed effect regression, production function, production frontier method, stochastic frontier production function and the inefficiency model ( Escribano, et al. 2005; Kinda, et al, 2011; Liu and Nishijima, 2012; Olley \& Pakes 1996; Dollar et al. (2004). The studies evaluate the impact of investment climate (IC) variables and other firm control (C) characteristics on several productivity measures and discovered that there exists consistently high impact of investment climate on firm-level productivity.

\section{Methodology}

\subsection{Description of the Dataset}

Following the ISIC (revision 3.1) classification, the following industries in Table 2 were covered by the 2009 World Bank Investment Climate Survey in Nigeria, 
Table 2: Types of Industries

\begin{tabular}{|l|l|c|c|c|}
\hline Industry type & Industry & Freq. & Percent & Cum. \\
\hline \multirow{5}{*}{ Manufacturing } & Food & 242 & 7.67 & 7.67 \\
\cline { 2 - 5 } & Garments & 169 & 5.35 & 13.02 \\
\cline { 2 - 5 } & Textiles & 14 & 0.44 & 13.46 \\
\cline { 2 - 5 } & machinery \& equipment & 13 & 0.41 & 13.87 \\
\cline { 2 - 5 } & Chemicals & 30 & 0.95 & 14.82 \\
\cline { 2 - 5 } & Electronics & 2 & 0.06 & 14.89 \\
\cline { 2 - 5 } & non-metallic minerals & 210 & 6.65 & 21.54 \\
\cline { 2 - 5 } & wood, wood products \& furniture & 414 & 13.11 & 34.65 \\
\cline { 2 - 5 } & metal \& metal products & 263 & 8.33 & 42.98 \\
\cline { 2 - 5 } & Other manufacturing & 233 & 7.38 & 50.36 \\
\hline Retail & Retail & 643 & 20.37 & 70.73 \\
\hline \multirow{5}{*}{ Rest of the universe } & information technology & 13 & 0.41 & 71.14 \\
\cline { 2 - 5 } & construction \& transport & 133 & 4.21 & 75.36 \\
\cline { 2 - 5 } & hotels \& restaurants & 143 & 20.11 & 95.47 \\
\cline { 2 - 5 } & Other & 3.157 & 100 & 100 \\
\hline & Total & & & \\
\hline
\end{tabular}

Source: World Bank Enterprise Data and authors' own calculation

The importance of each industry on three factors; gross output, value added and employees is presented in Table 3. Food and beverage processing sector as a whole is the second largest manufacturing group in Nigeria in terms of gross output, value added and number of employees. It is next in line to metal and metal products. Given the priority accorded food and beverage processing, the industry is expected to be more productive than others but table 4 shows that it is fifth in the order of importance based on gross output, value added and number of employee.

Table 3: Importance of industries

\begin{tabular}{|l|c|c|c|}
\hline Industry & Gross output & value added & Employee \\
\hline Chemicals & $1.07 \%$ & $1.05 \%$ & $1.01 \%$ \\
\hline Electronics & $0.11 \%$ & $0.12 \%$ & $0.14 \%$ \\
\hline Food & $7.24 \%$ & $7.17 \%$ & $7.31 \%$ \\
\hline Garments & $5.34 \%$ & $5.38 \%$ & $5.28 \%$ \\
\hline Machinery \& equipment & $0.54 \%$ & $0.54 \%$ & $0.52 \%$ \\
\hline Metal and metal products & $9.02 \%$ & $9.04 \%$ & $9.02 \%$ \\
\hline Non - metallic minerals & $7.03 \%$ & $7.13 \%$ & $7.26 \%$ \\
\hline Other manufacturing & $7.24 \%$ & $7.25 \%$ & $7.105 \%$ \\
\hline Textiles & $0.54 \%$ & $0.52 \%$ & $0.53 \%$ \\
\hline Wood, wood products and furniture & $12.65 \%$ & $12.71 \%$ & $12.58 \%$ \\
\hline retail & $19.56 \%$ & $19.42 \%$ & $19.34 \%$ \\
\hline Construction and transport & $4.15 \%$ & $4.17 \%$ & $4.23 \%$ \\
\hline Hotels and restaurants & $20.52 \%$ & $20.50 \%$ & $20.58 \%$ \\
\hline Information and technology & $0.37 \%$ & $0.40 \%$ & $0.40 \%$ \\
\hline Others & $4.59 \%$ & $4.63 \%$ & $4.71 \%$ \\
\hline Total & 100.00 & 100.00 & 100.00 \\
\hline
\end{tabular}

\subsection{Investment Climate}

A general list of various quantitative measures of the investment climate collected by the survey is presented in Table 4. The list sometimes contains multiple indicators covering a similar theme. The overall list of indicators in the survey are: duration of power outage, losses due to power outage as a percentage of total sales, percentage of electricity generated from generators, access to land, loss in transit due to breakage and spoilage as a percentage of sales, cost of security, management 
time in dealing with regulation, unofficial payments, days to register a phone line, water from public sources, inspection time, tax, overdraft facility and share with bank loan. The summary of descriptive statistics is presented in Table 4.

The Table indicates that there is high rate of power outage in Nigeria. Hence, Nigerian industries need standby generators for effective business operations. In respect of duration of power outage in number of hours per month, chemical and other industries are the worst hit by the challenge, followed by food and beverage and garments. Another measure of reliable power supply is the proportion of firms operating on their own generators. Apart from electronic industries, more than 60 percent of total electrical utilization by Nigerian manufacturing industries does not come from the public grid, but from their own generators. For machineries, chemical and other industries, the proportion is more than three quarters. In terms of losses due to power outage as a percentage of sales, food and beverage industries have the greatest loss followed by chemical. This shows that electricity is more important to food and beverage industry than other industries in Nigeria. After electricity, the next greatest concern is access to finance. Table 4 shows that the three industries with greatest overdraft facilities are textiles, food and beverages and chemicals. The share of firms with a loan from a bank or financial institution also varies quite a bit across the manufacturing industries. A major reason for the low share might be high demand for collateral security. The collateral requirement as a \% of loan is as high as $282.8 \%$ for food and beverage industries.

Another question that relates to investment climate indicator is how many days it took to secure a phone lines. The results show that all the manufacturing industries apart from wood appear relatively good (less than 16 days). An obvious reason for this success might be the privatization of Nigerian telecommunication industry that attracts good competition among various service providers and hence improvement in their efficiencies. The survey also asks the question on how many times per year the firms are visited by government inspectors. Table 4 indicates that the reported number of inspections is generally low. It is however higher in food and beverage industries than in other industries. A related question is how much time management spends dealing with government regulations. Here, the responses give a rather different picture. Chemical industries have the highest reported time (3.7\% of management time, compared to $4.9 \%$ in chemical, and $4.6 \%$ in food and beverages). The survey also includes questions about corruption, in terms of unofficial payments. The highest indicator of corruption is reported by textile industries $(6 \%)$ followed by other manufacturing industries $(5.4 \%)$ and electronics $(5 \%)$. The lowest is reported in garment industry.

In summary there is very significant variation in many of the investment climate measures across Nigerian manufacturing industries, so that the potential is there to explain differences in the performance of the industries based on variation in the investment climate.

Table 4: Sample Means of the Investment Climate Indicators ${ }^{1}$

\begin{tabular}{|l|c|c|c|c|c|c|c|c|c|c|}
\hline Industry & food & garment & textile & mach. & chem. & elect. & Nmet & wood & metal & other \\
\hline Pwout & 255. & 254.4 & 195.5 & 242.5 & 281.4 & 54.0 & 222 & 238.4 & 231 & 293.1 \\
\hline Mgt time & 4.6 & 3.7 & 1.9 & 4.9 & 7.0 & 3.0 & 2.9 & 3.5 & 3.7 & 5.2 \\
\hline Loss & 6.9 & 3.6 & 4.6 & 3.7 & 6.5 & 1.0 & 4.4 & 3.2 & 4.1 & 4.5 \\
\hline Land & 104 & 92.8 & .0 & 105.0 & 59.6 & .0 & 97.0 & 110.6 & 111 & 125.1 \\
\hline Gen & 67.6 & 62.7 & 53.1 & 78.4 & 76.5 & 50.0 & 73.3 & 65.8 & 69.5 & 73.7 \\
\hline TLoss & 2.4 & 0.6 & 1.4 & 1.7 & 3.5 & 1.0 & 3.9 & 1.3 & 0.8 & 1.4 \\
\hline SLoss & 4.3 & 5.0 & 0 & 2.6 & 8.0 & .0 & 4.9 & 4.3 & 5.2 & 4.3 \\
\hline Security & 3.4 & 4.3 & 0.1 & 4.8 & 2.7 & .0 & 4.1 & 3.3 & 2.6 & 2.2 \\
\hline
\end{tabular}

\footnotetext{
${ }^{1}$ power outage (pwout) is measured in number of hours/monthmgt time means management time in dealing with regulations, loss to power outage (Loss) is the share of such loss in total sales, Land is the number of days to process landed property, generator is the proportion of firms using generator, TLoss is loss in transit and SLoss is the percentage of shipment that is loss due to spoilage and thieves respectively, security bribe and tax are shares of each variable in total sales, phone is the number of days to obtain phone, water is the proportion of firms with access to public water, inspect means number of times visited by government officials, bdraft means using overdraft facility or not while loan refers to proportion of total financing from bank loan.
} 


\begin{tabular}{|l|c|c|c|c|c|c|c|c|c|c|}
\hline Industry & food & garment & textile & mach. & chem. & elect. & Nmet & wood & metal & other \\
\hline Bribe & 3.6 & 2.2 & 6.0 & 4.6 & 4.3 & 5.0 & 4.0 & 3.5 & 3.2 & 5.4 \\
\hline Phone & 15.8 & 24 & 0 & 12 & 11.8 & 15 & 31.7 & 12.7 & 4.6 & 14.6 \\
\hline Water & 28.3 & 31.8 & 8.1 & 47.0 & 32.5 & 60.0 & 27.2 & 29.6 & 28.9 & 32.5 \\
\hline Inspect & 3.7 & 3.5 & 2.1 & 1.7 & 3.5 & 2.0 & 2.7 & 3.3 & 3.4 & 3.5 \\
\hline Tax & 72.7 & 72.2 & 74.4 & 70.8 & 73.6 & 65.0 & 68.2 & 67.7 & 66.4 & 71.0 \\
\hline bdraft & 26.6 & 4.1 & 57.1 & 7.7 & 46.7 & 0 & 11.9 & 9.9 & 13.7 & 16.7 \\
\hline loan & 5.2 & 0.6 & 8.2 & 2.3 & 12.3 & 0.0 & 1.2 & 1.8 & 3.3 & 2.9 \\
\hline
\end{tabular}

Note: mach means manufacturing, chem means chemical, elect means electrical and nmet means non-metallic

\subsection{Output, Labour, Capital, Materials and Firms' Characteristics}

The measures of output for the production function estimation in this study, is sales measured in Naira, for all the manufacturing industries. It can be seen from Table 5 that, the total sales vary from 10 million Naira to 511 million. On the average, chemical industries recorded the highest sales, followed by food and textiles. A measure of labour taken into consideration in the empirical analysis is the number of employee. This measure is preferred to value unit because, wages are expected to diverge across industries. The average number of employees ranged from 10 to about 72 . Apart from chemical and food and beverage industries, all the industries are dominated by small scale firms, which employ between 5 and 19 workers (Table 5 column 6). In food and beverage industry, medium and large scale firms ( 20 and above employees) are more prevalent than small firms. This underscores the relevance of agro-industrialization in Nigerian economy. The costs of production (materials and capital) vary across Nigerian manufacturing industries. On the average, the book value of fixed assets varies between 2 and 300 million Naira. Table 5 further indicates that chemical industry is the most capital intensive followed by food and beverage. Food and beverage industry, however, spend more on materials and intermediate inputs than other industries. For most of the manufacturing industries, more than $90 \%$ of the firms are non-exporters. The proportions are $99.4 \%, 99 \%$, and $96.3 \%$ in garment, metal and food and beverage industries respectively. The highest proportion of exporters is reported in textile industry $(22.4 \%)$. The low proportion of exporters might not be unconnected with the prevailing investment climate in the country, particularly, long duration of power outage and poor credit rating. They may create serious bottleneck, when firms are required to meet foreign demand for their products. The survey includes question on percentage of firm owned by private domestic, companies, individual and organization. Table 5 shows that, more than $90 \%$ of firms in each manufacturing industry, are owned by private domestic, individual, companies and organization. The proportions are 99.5\%, 99.0, 98.8 and 96.3 for non-metal, wood, metal and food and beverage industries respectively. In order to control for the quality of labour, the survey contains a question on the highest educational qualification of the firms' manager. Apart from chemical industry, more than $50 \%$ of managers in Nigerian manufacturing industries possess less than first degree.

Table 5: Descriptive Statistics: Production Data and Firms' Characteristics

\begin{tabular}{|c|c|c|c|c|c|c|c|c|}
\hline Industry & $\begin{array}{c}\text { Sales } \\
\text { (Nmillions) }\end{array}$ & Labor & $\begin{array}{c}\text { Capital } \\
\text { (NMillions) }\end{array}$ & $\begin{array}{c}\text { Materials } \\
\text { (NMillions) }\end{array}$ & Small Scale \% & $\begin{array}{c}\text { Ownership } \\
\text { (domestic) }\end{array}$ & Non-Exporter & $\begin{array}{c}\text { At least First } \\
\text { degree }\end{array}$ \\
\hline Food & 511 & 70.4 & 96.9 & 296 & 38 & 96.3 & 96.3 & 44.0 \\
\hline & 242 & 242.0 & 242 & 242 & 242.0 & 242.0 & 242.0 & 25.0 \\
\hline Garments & 10 & 12.7 & 2.1 & 4.1 & 72.2 & 99.0 & 99.4 & 25 \\
\hline & 169 & 169.0 & 161 & 169 & 161.0 & 169.0 & 169.0 & 12.0 \\
\hline Textiles & 178 & 45.4 & 107 & 95.2 & 50 & 92.8 & 78.6 & 33.3 \\
\hline & 14 & 14.0 & 14 & 14 & 14.0 & 14.0 & 14.0 & 6.0 \\
\hline Machinery & 105 & 28.6 & 13.2 & 44.9 & 61.5 & 92.3 & 84.6 & 0.0 \\
\hline & 13 & 13.0 & 13 & 13 & 13.0 & 13.0 & 13.0 & 2.0 \\
\hline chemicals & 808 & 72.3 & 300 & 457 & 30 & 86.7 & 83.3 & 100.0 \\
\hline & 30 & 30.0 & 30 & 30 & 30.0 & 30.0 & 30.0 & 11.0 \\
\hline Electronic & 13.9 & 16.0 & 1.3 & 5.5 & 50 & 88.0 & 99.0 & 0 \\
\hline & 2 & 2.0 & 2 & 2 & 2.0 & 2.0 & 2.0 & 0.0 \\
\hline
\end{tabular}




\begin{tabular}{|c|c|c|c|c|c|c|c|c|}
\hline Industry & $\begin{array}{c}\text { Sales } \\
\text { (Nmillions) }\end{array}$ & Labor & $\begin{array}{c}\text { Capital } \\
\text { (NMillions) }\end{array}$ & $\begin{array}{c}\text { Materials } \\
\text { (NMillions) }\end{array}$ & Small Scale \% & $\begin{array}{c}\text { Ownership } \\
\text { (domestic) }\end{array}$ & Non-Exporter & $\begin{array}{c}\text { At least First } \\
\text { degree }\end{array}$ \\
\hline non-metal & 49.2 & 17.9 & 12.4 & 2.2 & 76.7 & 99.5 & 99.0 & 19.1 \\
\hline & 210 & 210.0 & 208 & 210 & 209.0 & 210.0 & 210.0 & 68.0 \\
\hline Wood & 58.6 & 15.0 & 8 & 32.2 & 77.1 & 99.0 & 99.0 & 27.4 \\
\hline & 414 & 414.0 & 396 & 414 & 404.0 & 414.0 & 414.0 & 62.0 \\
\hline metal & 65.3 & 16.2 & 35.6 & 32.4 & 76.8 & 98.8 & 97.3 & 33.3 \\
\hline & 263 & 263.0 & 253 & 263 & 255.0 & 263.0 & 263.0 & 33.0 \\
\hline Others & 105 & 22.0 & 348 & 55.4 & 67.8 & 98.7 & 96.6 & 44.4 \\
\hline & 233 & 233.0 & 228 & 233 & 229 & 233.0 & 233.0 & 54.0 \\
\hline
\end{tabular}

\subsection{Empirical Model Specification and Estimation Technique}

Following common practice in empirical literature, the analysis begins with estimation of equations 2 - 4. In order to assess the effects of investment climate variables on the productivity of the firms of the business environment. The World Bank Investment Climate (ICA) surveys made available information on a large number of investment climate (IC) variables as well as general information on firms' status, productivity, sales and supplies. In the questionnaire, the IC variables are classified into 6 broad categories: (a) Infrastructures and Services, (b) Finance, (c) Business-Government Relations, (d) Conflict Resolution/Legal Environment, (e) Crime, and (f) Capacity, Innovation, Learning. Based on description of the investment climate in Table 4, the following variables are used to provide an overall representative of the business environment: duration of power outage, losses due to power outage as a percentage of total sales, percentage of electricity generated from generators, access to land, loss in transit due to breakage and spoilage as a percentage of sales, cost of security, management time in dealing with regulation, unofficial payments, days to register a phone line, water from public sources, inspection time, tax, overdraft facility and share with bank loan. The firm characteristics include size: Ranking: Small $=1$, Medium $=2$ and Large $=3$, Export: Percentage of establishment's sales scheduled for direct exports and Ownership: Percentage of this firm owned by private domestic individuals, companies and organizations. The empirical model is shown in equation 7.

$T F P_{i}=$ cons $+a(F)+b(X)+$ cindustry $_{i}+v_{i}$

Where

$T_{T F P}$ : Total Factor productivity (estimated from production model with highest wald chi2)

$F$ : Vector of firms' characteristics

$x$ : Vector of investment climate variables

industry :Industry dummy variables

$a, b, c$ : Regression coefficients

$v_{i}:$ Disturbance term

Larossi et al (2011) reports that most of the investment climate constraints are potentially endogenous. It is often difficult in practice to find instruments for all investment climate variables that could be included in firm performance regressions. The common solution to the endogeneity problem is therefore to instrument or replace the firms'own constraints with the average constraints by firms in the same city, sector and region. Aterido et al (2011) show that, controlling for endogeneity can have a large effect on results. They find that access to finance, corruption, and power have a far more modest impact on firm growth after controlling for endogeneity. In this study, therefore, city-sector averages of investment climate indicators and firm characteristics are computed to control for endogeneity. The estimation of the TFP model begins with only the investment climate indicators. The basic model is augmented by inclusion of firms' characteristics described in Table 5. As a robustness check, industry dummies are also included.

\section{Results and Discussion}

\subsection{Production Function for Nigerian Manufacturing Industries}

The basic estimation results for the CD production function at industry level are reported in Table 6 
Column 1 reports the results of the model that controls for only labour, capital and material. The regression result, when the educational qualification of the firms' manager is included in the model, is reported in column 2. The last two columns show the validity tests of a common technology across the manufacturing industries. In the model estimation, a random effects specification is used to capture possible unobserved heterogeneity across firms. The firms are pooled across cities. The results in column 1, Table 6 indicates that the coefficients of labour, capital and materials are all positive as expected apriori and statistically significant at the $1 \%$ level of significance. The elasticities of output with respect to labour and capital are 0.24 and 0.03 respectively. This indicates that a $1 \%$ rise in number of employee and capital stock will generate $0.24 \%$ and $0.03 \%$ increase in output respectively. In column 2 , the coefficient on manager's education is significant but labour elasticity is reduced to 0.22 while the coefficient of capital becomes insignificant. In both cases, the production of manufacturing industries in Nigeria is experiencing increasing return to scale. The positive output elasticities with respect to labour and capital shows that the use of the inputs in Nigerian manufacturing industries will enhance production. This indicates that the relationship between output and the inputs are complimentary in nature.

Table 6: Production Function Estimates

\begin{tabular}{|c|c|c|c|c|}
\hline Variable & model1 & model2 & model3 & model 4 \\
\hline Log(labour) & $0.239(9.081)^{\star \star \star}$ & $0.221(4.433)^{\star \star \star}$ & $0.238(9.206)^{\star \star *}$ & $0.218(4.526)^{\star \star \star}$ \\
\hline Log(capital) & $0.039(7.162)^{\star \star \star}$ & $0.013(0.907)$ & $0.0401(6.578)^{\star \star \star \star}$ & $0.009(0.646)$ \\
\hline Log(material) & $0.726(43.799)^{\star \star \star \star}$ & $0.768(22.037)^{\star * \star}$ & $0.729(44.472)^{\star * \star}$ & $0.768(22.076)^{\star \star \star}$ \\
\hline Log(education) & & $0.022(1.915)^{\star \star}$ & & $0.0234(1.921)^{\star \star}$ \\
\hline \multicolumn{5}{|l|}{ Industry } \\
\hline Garments & & & $0.0583(1.161)$ & $-0.02(-0.151)$ \\
\hline Textiles & & & $0.116(1.863)^{*}$ & $0.193(1.554)$ \\
\hline Machinery & & & $0.042(0.434)$ & $0.241(1.425)$ \\
\hline Chemicals & & & $0.014(0.291)$ & $-0.08(-1.553)$ \\
\hline Electronic & & & $0.142(0.918)$ & \\
\hline Non-metal & & & $0.002(0.069)$ & $-0.102(1.812)^{*}$ \\
\hline Wood & & & $0.029(1.151)$ & $-0.061(1.011)$ \\
\hline Metal & & & $0.032(1.095)$ & $-0.021(0.402)$ \\
\hline Others & & & $0.018(0.636)$ & $-0.053(0.903)$ \\
\hline Cons & $3.9892(18.925)^{\star \star \star}$ & $3.646(9.338)^{\star * \star}$ & $3.885(17.787)^{\star \star \star \star}$ & $3.749(8.992)^{\star \star \star}$ \\
\hline
\end{tabular}

The assumption of a common technology across industries is validated in Table 7, when the regression coefficients are allowed to vary by industries. As expected theoretically, the coefficients of labour, capital and material are positive and statistically significant at 1\% probability level. Given the results of the wald chi square, the regression result presented in Table 6 column 1 is more robust than others. Hence, the residuals are used to generate a measure of TFP.

Table 7: Production Function with Interaction Terms

\begin{tabular}{|c|c|c|}
\hline Variable & model5 & model6 \\
\hline Log(labour) & $0.236(5.570)^{\star \star *}$ & $0.128(2.171)^{\star \star}$ \\
\hline Log(capital) & $0.040(5.325)^{\star \star *}$ & $0.022(1.604)^{\star}$ \\
\hline Log(material) & $0.727(43.888)^{\star * \star}$ & $0.776(22.663)^{* * *}$ \\
\hline Food*Log(labour) & $0.051(1.384)$ & $0.144(3.052)^{\star \star \star}$ \\
\hline Garment*Log(Labour) & $-0.034(-0.76)$ & $0.187(1.173)$ \\
\hline Textile*Log(Labour) & $-0.0306(-0.422)$ & $-0.1891(-0.613)$ \\
\hline Machinery*Log(Labour) & $-0.0255(-0.254)$ & $0.8258(3.6927)^{\star \star \star}$ \\
\hline${\text { Chemical }{ }^{\star} \text { Log(Labour) }}$ & $0.0184(0.249)$ & $0.259(3.7593)^{\star \star \star}$ \\
\hline Electronics*Log(Labour) & $-0.2971(7.787)^{\star \star \star}$ & (omitted) \\
\hline Non-metal*Log(Labour) & $-0.0118(-0.284)$ & $0.0581(1.121)$ \\
\hline
\end{tabular}




\begin{tabular}{|c|c|c|}
\hline Variable & model5 & model6 \\
\hline Wood*Log(Labour) & $-0.0375(0.779)$ & $0.0212(0.424)$ \\
\hline Metal*Log(Labour) & $0.0213(0.445)$ & $0.1196(1.708)$ \\
\hline Food*Log(Capital) & $-0.0106(-1.596)$ & $-0.0257(-2.349)^{\star \star}$ \\
\hline Garment*Log(Capital) & $0.008(0.994)$ & $-0.0348(-0.996)$ \\
\hline Textile*Log(Capital) & $0.0119(0.839)$ & $0.0426(0.809)$ \\
\hline Machinery*Log(Capital) & $0.007(0.323)$ & $-0.1195(-3.294)$ \\
\hline Chemical*Log(Capital) & $-0.0028(-0.177)$ & $-0.0573(-4.045)$ \\
\hline Electronics* ${ }^{\star}$ og(capital) & $0.0652(10.134)^{\star \star *}$ & (omitted) \\
\hline Non-metal*Log(Capital) & $0.0007(0.098)$ & $-0.0154(-1.443)$ \\
\hline Wood*Log(Capital) & $0.0066(0.921)$ & $-0.0058(-0.549)$ \\
\hline Metal ${ }^{*} \log ($ Capital) & $-0.0028(-0.379)$ & $-0.0223(-1.732)$ \\
\hline Educ & & $0.03(2.539)^{\star *}$ \\
\hline cons & $3.9437(18.304)^{\star \star \star}$ & $3.5879(8.992)^{\star \star \star}$ \\
\hline
\end{tabular}

\subsection{TFP Distribution by Industry}

Figure 1 presents the average of firm-level TFP by industry. Splitting the sample in 10 sectors has been justified by the fact that firms in each industry use more or less a similar technology. The TFPs are presented in percent of the average TFP of the most performing industry. The results reveal that chemical industry is well above their peers in productivity, followed by other manufacturing industries and food and beverages.

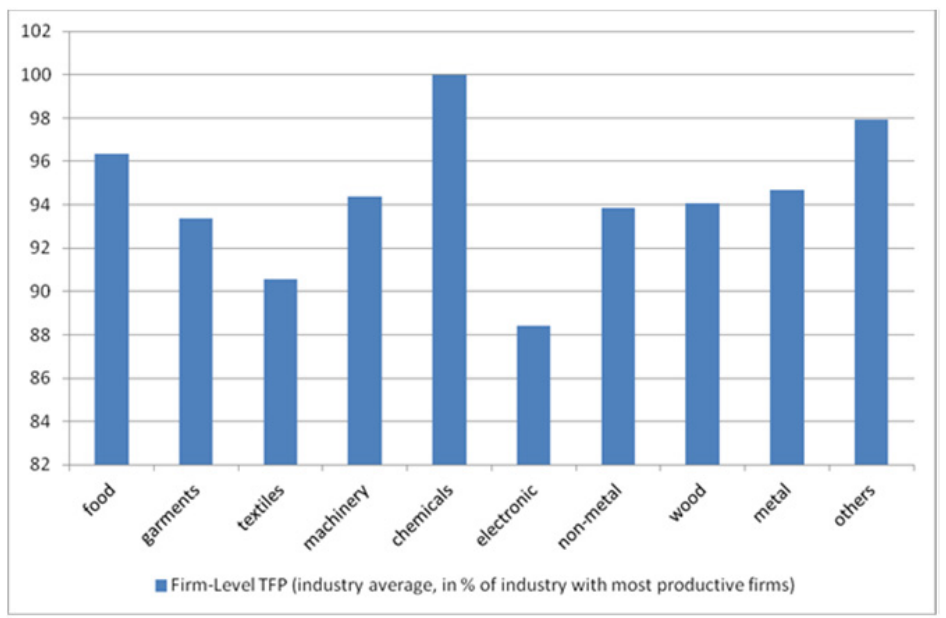

Figure 1: Firm-Level TFP

\subsection{What types of industry perform better than others?}

Table 8 shows the results of estimating the relationship between TFP and investment climate variables. All the variables are statistically significant with expected signs when ownership is included in the model. The variables, size and export, are excluded because their effects were not robust. The lack of significance of size may be explained by the argument that the manufacturing firms are predominantly small scale. The insignificance of export may be due to the fact that the domestic market is so large that the share of an individual exporter does not much affect its performance. The results show that unofficial payment is critical to performance of manufacturing industries in Nigeria. The variable is positive and significant in the model. This might be due to the need to comply with regular demands of National Agency for Food and Drug Administration and Control (NAFDAC) and Standard Organization of Nigeria (SON) for sustainability of their 
operations. Another interesting aspect of the results is that duration of power outage negatively and strongly influences productivity of Nigerian manufacturing industries. This confirms the yearnings of Nigerians to improve the power sector in the country. The result also shows that the management time for dealing with regulations is positive and statistically significant. This indicates that the more attention paid to legislations and regulations especially those relating to product conformance, the better the productivity of manufacturing industries in Nigeria. This gives credence to the efficacy of government's organs for enforcing compliance with industrial regulatory policies such as Standard Organization of Nigeria (SON), National Agency for Food, Drug and Administration Control (NAFDAC) and Federal Produce Inspection Services (FPIS).

Table 8: Investment Climate and TFP

\begin{tabular}{|c|c|c|}
\hline Variable & TFP model 1 & TFP model 2 \\
\hline Power outage time & $-0.00069(-3.102)^{\star * \star}$ & $-0.0006(-4.20)^{\star \star \star}$ \\
\hline Management time dealing with regulation & $0.032(4.286)^{\star \star \star}$ & $0.0235(3.666)^{\star \star \star}$ \\
\hline Electricity from generator (\%) & $0.0052(3.506)^{\star \star \star *}$ & $0.0063\left(5.1850^{* * *}\right.$ \\
\hline Transit loss to breakage/spoilage & $-0.0226(-2.309)^{\star \star}$ & $-0.0263(-3.383)^{\star * \star}$ \\
\hline Unofficial payment (\% sales) & $-0.0179(-3.218)^{\star \star \star}$ & $-0.0087(-1.698)^{\star}$ \\
\hline Day to phone line & $0.0007(1.118)$ & $0.0016(2.692)^{\star *}$ \\
\hline Inspections per year & $0.0141(1.628)^{*}$ & $0.0121(1.761)^{\star}$ \\
\hline Tax per year & $-0.0023(-1.627)^{\star}$ & $-0.0035(-2.971)^{\star *}$ \\
\hline Ownership & & $1.936(3.371)^{\star \star \star}$ \\
\hline cons & $0.8368(9.923)^{\star \star \star}$ & $0.8439(12.691)^{\star \star \star}$ \\
\hline$\overline{\mathrm{N}}$ & 26 & 26 \\
\hline r2 a & 0.6454 & 0.7797 \\
\hline
\end{tabular}

\section{Summary and Policy Implications}

This study examines the influence of investment climate on the total factor productivity (TFP) of manufacturing industries in Nigeria. The study is conducted in two phases namely (i) an estimation of industry and firm-level productivity measures js carried out and, (ii) differences in TFP across firms is statistically related to indicators of investment climate, taking into consideration firms characteristics. The analyses use 2009 World Bank Enterprise survey data on Nigeria. In terms of firm level productivity, chemical industry is more productive than others. The results show that the empirical relationship between investment climate indicators and firm performance is robust to the inclusion of industry dummies, which reveals that there is significant variation in the investment climate across manufacturing industries in the country. So, industrial policy plan is important.

The empirical results further indicate that the following investment climate are the most important bottlenecks to productive performance of manufacturing industries in Nigeria: duration of power outage, time spent by management in dealing with state and federal government regulations, unofficial payments, inspections per year, percentage of electricity from generators, loss in transit due to breakage and spoilage, tax paid per year and ownership of firm. As expected a priori, power outage, unofficial payment, tax and loss in transit due to breakage or spoilage negatively and significantly affect TFP of manufacturing industries in Nigeria, while the influence of other variables is positive and significant.

The results show that there are scopes for initiating policy measures to improve the dimensions of the relevant investment climate indicators. Hence, the following policies are suggested to enhance competitiveness of Nigerian manufacturing industries:

i. In order to ensure a stable and sufficient supply of power for industrial use, a roadmap for the currently passed power reform should be initiated. For instance, the frequency and length of power outage could be reduced by improving the public grid through increase in generation capacity and promotion of pricing and distributional efficiencies currently in use. In addition, clean energy generation through solar system and inverter by private firms, should be given maximum support fund, at single digit interest rate.

ii. Road infrastructure should be given adequate attention; one major issue with roads in 
Nigeria is that, they are not strong enough for trucks moving raw materials and firms' products across various markets. This might be responsible for significant loss in transit due to breakage and spoilage. While it is expedient for government to intensify her efforts on construction of modern railway system, road construction and repair should take cognizance of the high number of trucks for smooth running of the nation's industrial operations.

iii. Appropriate measures should be put in place to reduce the rate of unofficial payments and tax disincentives in the country.

\section{Acknowledgement}

We wish to express our deep appreciation to African Economic Research Consortium (AERC) fpr the financial support to carry out this research. We are also grateful to the resource persons and members of AERC's thematic group $D$ for various comments and suggestions that helped the evolution of this study from its inception to completion. We are indebted to the anonymous referees who reviewed the paper and provide comments and suggestions that helped in shaping and improving the overall quality of the paper. The findings made and opinions expressed in this paper are exclusively ours. We are solely responsible for the content and any errors, All errors should, however, be considered as ours.

\section{References}

Ajetomobi ,J. O., (2011). TotsI Factor Productivity of Agricultural Commodities in the Economic Community of West Africa States: 1961-2005. AERC Research Paper 241.

Barro R. J., \& Sala - Martin, X., (2004). "Economic Growth", McGraw Hill, New York (2004).

Bartelsman, E. J. \& Mark Doms (2000). "Understanding Productivity: Lessons from Longitudinal Microdata.." Journal of Economic Literature 38(3)

Bastos, F., \& Nasir, J. (2004). Productivity and Investment Climate; What Matters Most?. World Bank Policy Research paper 3335 , June.

Chete L. N \& Adenikinju, A. F. (2002). Productivity growth in Nigerian manufacturing and its correlation to trade policy regimes/indexes (1962-1985). AERC Research Paper 127Collard-Wexler,

Dollar, D., Anqing Shi, Shuilin Wang \& Colin. Xu, L. (2004). "Improving City Competitiveness through the Investment Climate: Ranking 23 Chinese Cities". Washington, D.C., World Bank.

Dollar, D., Hallward-Dreimeier, M. \& Mengistae, T..( 2005): "Investment Climate and Firm Performance in Developing Countries." Economic Development and Cultural Change 54(1):1-31.

Escribano, A., \& Guasch, J. L..( 2005). "Assessing the Impact of the Investment Climate on Productivity Using Firm-Level Data: Methodology and the Cases of Guatemala, Honduras and Nicaragua." Policy Research Working Paper 3621. World Bank, Washington DC. Available on line at http://go.worldbank.org/F4W5VBGDRO.

Diewert W. E. \& Nakamura, A. O. (2002). "The Measurement of Aggregate Total Factor Productivity Growth". J. J. Heckman and E. E. Leamer (eds.). Handbook of Econometrics, Vol. 6, forthcoming.

Foster, L., J. Haltiwanger \& Krizan, C. J. (1998). "Aggregate Productivity Growth: Lessons from Microeconomic Evidence". NBER Working Paper W6803.

Hall, R. E. (1990). "Invariance Properties of Solow's Productivity Residual". In Peter Diamond (ed.). Growth, Productivity, Employment. Cambridge: MIT Press, 1-53.

Hulten, C R (2001). 'Total factor productivity: a short biography', in Hulten, C R, Dean, E R and Harper, M J (eds), New developments in productivity analysis, Chicago, Chicago University Press

Jorgenson, D. W., Mun S. H., \& Kevin, J. S.. (2005). Productivity. Volume 3. Information Technologyand the American Growth Resurgence. Cambridge and London: MIT Press.

Jorgenson, D. W., Gollop, F. M. \& Barbara M. F. (1987). Productivity and U.S. Economic Growth, Cambridge, MA: Harvard University Press.

Kinda, T., Plane, P.., \& Varondakis, M. V.,(2008). Productivity and Technical Efficiency in MENA Manufacturing Industries: The Role of the Business Environment. Equity and Economic Development ERF 15th Annual Conference 23rd - 25th November 2008. Marriott Cairo Hotel, Cairo, Egypt.

Kinda, T., Plane, P., \& Varondakis, M. V.,(2011): Firm Productivity and Investment Climate in Developing Countries. How does Middle and North African manufacturing perform? IMF, Washington D. C. CERDI, Etudes et Documents, 2011.26.

Larossi, G. \& Clarke, G. R. G. (2011). An assessment of the investment climate in 26 states. African Finance 
and Private Sector Development (AFTFP) World Bank,

Liu, W., \& Nishijina, S. (2012): Productivity and Openness: Firm Level Evidence in Brazilian manufacturing Industries. Discussion paper series RIEB Kobe University. DP2012 - 01. 2 - 1 Rokkodai, Nada, Kobe 657 - 8501 Japan.

Olley, G. S., \& Pakes, A. (1996). The Dynamics of Productivity in the Telecommunications Equipment Industry. Econometrica, 64(6), 1263-97

Seliola, F \& Seker, M. (2011). Total Factor Productivity Across the Developing World. Enterprise Note Series 2011.

Solow, R. M. (1957). "Technical Change and the Aggregate Production Function,". Review of Economics and Statistics, 39(3), 312-320

Syverson, C. (2004). "Market Structure and Productivity: A Concrete Example." Journal of PoliticalEconomy, 112(6): 1181-1222.

Syversion, C. (2011). What Determines Productivity? Journal of Economic Literature 2011, 49:2, 326-365 http:www.aeaweb.org/articles.php?doi=10.1257/jel.49.2.326 326

Veeramani, C. \& Bishwanat, G. (2004). Investment climate and total factor productivity in manufacturing: analysis of Indian states. Indian Council for Research on International Economic Relations Working Paper 127. 